
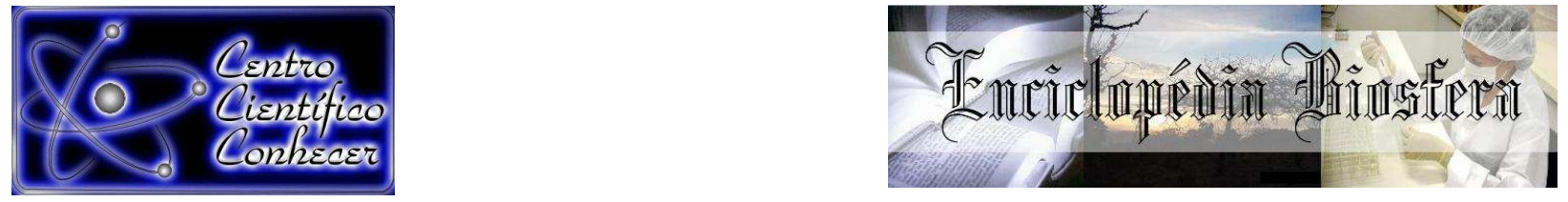

\title{
MEAT QUALITY OF SWINE SUPPLEMENTED IN THE PRE-SLAUGHTER PERIOD WITH MAGNESIUM, ZINC, SELENIUM AND COPPER
}

Luana Ribeiro Alves ${ }^{1}$, Robson Carlos Antunes ${ }^{2}$, Andressa Alves Storti ${ }^{3}$, Serly Lourenço Borges Reis ${ }^{1}$, Alysson Oliveira Resende ${ }^{4}$

1. Mestre em Produção Animal pela Universidade Federal de Uberlândia(UFU)

2. Professor Doutor da Faculdade de Medicina Veterinária da Universidade Federal de Uberlândia (UFU)

3. Doutoranda do Programa de Pós Graduação em Ciências Veterinárias da Universidade Federal de Uberlândia (UFU) (bystorti@yahoo.com.br)

4. Graduado em Medicina Veterinária pela Universidade Federal de Uberlândia(UFU)

Recebido em: 08/04/2017 - Aprovado em: 10/06/2017 - Publicado em: 20/06/2017 DOI: 10.18677/EnciBio 2017A70

\begin{abstract}
The aim of this study was to evaluate the effects of minerals (magnesium, copper, zinc and selenium) added to drinking water in pre-slaughter, on the final quality of pork. For each of the minerals tested, a total of 40 pigs ( 20 treated and 20 controls) were studied, housed in two rest pens, from a slaughterhouse in the municipality of Uberlândia. Inorganic sources of minerals $\left(\mathrm{Mg}_{2} \mathrm{SO}_{4}, \mathrm{Zn}_{2} \mathrm{SO}_{4}, \mathrm{Na}_{2} \mathrm{SeO}_{3}, \mathrm{Cu}_{2} \mathrm{SO}_{4}\right)$ were used and the administration period was 12 hours. The animals were slaughtered, and the following meat characteristics were measured and analyzed: $\mathrm{pH}$ at $45 \mathrm{~min}$ and 24 $\mathrm{h}$, meat color, water holding capacity (WHC), temperature at $1 \mathrm{~min}$ and $24 \mathrm{~h}$, and hot carcass weight $(\mathrm{HCW})$. The pigs submitted to the water diet containing the magnesium mineral as well as the selenium mineral presented better $\mathrm{pH} 45 \mathrm{~min}, \mathrm{pH}$ 24h and CRA than those that were not submitted to it. In addition, the meat color was paler in swine that had no access to magnesium. It was concluded that the pigs submitted to the water diet containing the magnesium and selenium minerals for a period of 12 hours presented a meat quality superior to those that were not supplemented.
\end{abstract}

KEYWORDS: water, water holding capacity, meat color.

\section{QUALIDADE DA CARNE DE SUÍNOS SUPLEMENTADOS COM MAGNÉSIO, ZINCO, SELÊNIO E COBRE NO PERÍODO PRÉ-ABATE}

\section{RESUMO}

Objetivou-se avaliar os efeitos dos minerais (magnésio, cobre, zinco e selênio) adicionados à água de bebida no pré-abate, na qualidade final da carne suína. Para cada um dos minerais testados, foram estudados um total de 40 suínos ( 20 tratados e 20 controles) alojados em duas pocilgas de descanso de um matadouro frigorífico no município de Uberlândia. Foram utilizadas fontes inorgânicas de minerais $\left(\mathrm{Mg}_{2} \mathrm{SO}_{4}\right.$, $\mathrm{Zn}_{2} \mathrm{SO}_{4}, \mathrm{Na}_{2} \mathrm{SeO}_{3}, \mathrm{Cu}_{2} \mathrm{SO}_{4}$ ) e o período de administração foi de 12 horas. Os animas foram abatidos, sendo mensuradas as seguintes características de qualidade de carne: $\mathrm{pH}$ aos 45 minutos e 24 horas, cor da carne, capacidade de retenção de água (CRA), as temperaturas à 1 minuto e 24 horas e o peso da carcaça quente (PCQ). 
Os suínos submetidos à dieta hídrica contendo o mineral magnésio, bem como o mineral selênio apresentaram melhor $\mathrm{pH} 45 \mathrm{~min}$, $\mathrm{pH} 24 \mathrm{~h}$ e CRA do que aqueles que não foram submetidos à mesma. Além disso, a cor da carne foi mais pálida nos suínos que não tiveram acesso ao mineral magnésio. Conclui-se que os suínos submetidos à dieta hídrica contendo os minerais magnésio e o selênio, por um período de $12 \mathrm{~h}$ apresentaram uma qualidade de carne superior àqueles que não foram suplementados.

PALAVRAS-CHAVE: água, capacidade de retenção de água, cor da carne.

\section{INTRODUCTION}

Meat is one of the most nutritious foods in the human diet. According to MATEESCU et al. (2013) of the most consumed animal protein foods, red meat is one of the best sources of iron and zinc easily absorbed. In many countries pork consumption accounts for more than half of the meat consumption. Consumers who prefer pork are changing their thinking of quantity to meat quality (KIM et al., 2016). In Brazil, although pork is consumed less than other meats, the country is the fourth largest pork consumer and exporter in the world (ABPA, 2016).

The pork quality involved factors such $\mathrm{pH}$, color, tenderness, water holding capacity and chemical composition (KIM et al., 2016) and all of these factors are influenced by breed and heredity as well as processes involved in breeding, slaughtering, meat processing, and storage (TOMOVIC et al., 2014).

Some characteristics of pork depends important attributes such as waterholding capacity, colour and oxidative stability, which are decisive in terms of suitability for processing and storage. Unacceptable color, water retention or product stability are important to influence consumer behavior, but can also cause high economic losses in the processing industry (CALVO et al., 2016). According to TOMOVIC et al. (2014), the drop in post-mortem pH is an important factor for meat color and water holding capacity

DJINOVIC-STOJANOVIC et al. (2017) cite that the investigation of essential elements in meat and meat products has been of increasing interest, considering the fact that these elements can improve meat quality. This has been the focus of many studies, and some authors have studied the supplementation of swine diet with minerals as a way of improving some of the parameters of performance and quality in pork.

The aim of the present study was to assess the impact of the addition of the minerals magnesium, zinc, copper and selenium to pre-slaughter drinking water on the final quality of the meat from swine slaughtered in a refrigerated slaughterhouse.

\section{MATERIAL AND METHODS}

This experiment was approved by the ethics committee for animal use under the protocol CEUA/UFU 111/10. A total of one hundred and sixty 150-day-old male and female swine from a commercial farm in the city of Patos de Minas, MG. The animals belonged to a commercial lineage created by the following cross-breeding: (Large White and Pietran) $x$ (Large White and Duroc).

For each of the four minerals tested, $\mathrm{Mg}, \mathrm{Zn}, \mathrm{Cu}$, and Se, 20 animals were treated and 20 animals served as controls. One mineral was tested per day in drinking water 12 hours before slaughter, and as such, 40 animals were studied per day. 
The animals were transported to the refrigerated slaughterhouse in adapted trucks under official inspection. After unloading, 40 swine from the same batch were randomly chosen and housed in two previously prepared resting pens. A total of 10 males and 10 females were housed in each pen, where they stayed for $12 \mathrm{~h}$, during which they were rested, fasted, and administered the specific water with a mineral supplementation. Group 1 consisted of the control animals, and group 2 consisted of the animals treated with the mineral source.

For the experiment, two similar side-by-side pens, $8.0 \mathrm{~m}$ long and $5.0 \mathrm{~m}$ wide, were chosen and prepared prior to the arrival of the swine. The drinking troughs were composed of PVC piping and valves, two 500-L water reservoirs (Fortlev®), a lowpressure rubber hose, and eight pacifier-like swine water troughs. Each water reservoir was graded and placed in each pen so that the animals' water intake could be monitored. The amount of water held by the piping was measured with a graded bucket (CIPLA® 17L), and for each pen, this amount was found to be $3 \mathrm{~L}$. Prior to the arrival of the animals, the reservoirs were sanitized and immediately filled with $250 \mathrm{~L}$ of water.

Before starting the experiment, samples of the water in the pens used for the experiments were analyzed by physical-chemical analysis for mineral composition and existing contents, as well as quality-related aspects.

The mineral dosages administered in the experiment were calculated based on the recommendations of the National Research Council (NRC, 2005), which recommends the maximum mineral levels to be used for each swine species, being: Mg 300ppm; Cu 250ppm; Se 2ppm e Zn 1000ppm.

The study used inorganic mineral sources. After dissolved in water, the concentrations of the respective minerals were calculated, as listed in Table 1.

TABLE 1. Sources and predicted amounts of minerals diluted into $250 \mathrm{~L}$ of water in the experiment. The amounts were based on the maximum tolerable levels for the swine species. Uberlandia - MG, 2011.

\begin{tabular}{llll}
\hline Mineral & Source & Mineral concentration in the source $(\%)^{*}$ & $\mathbf{g} / \mathbf{2 5 0} \mathbf{L}$ of water \\
\hline $\mathrm{Mg}$ & $\mathrm{Mg}_{2} \mathrm{SO}_{4}$ & 9.10 & 824.17 \\
$\mathrm{Cu}$ & $\mathrm{Cu}_{2} \mathrm{SO}_{4}$ & 24.8 & 252.01 \\
$\mathrm{Se}$ & $\mathrm{Na}_{2} \mathrm{SeO}_{3}$ & 45.0 & 1.11 \\
$\mathrm{Zn}$ & $\mathrm{Zn}_{2} \mathrm{SO}_{4}$ & 20.3 & $1,231.54$ \\
\hline
\end{tabular}

${ }^{*}$ Data provided by the manufacturer

The additional $3 \mathrm{~L}$ of water in the piping was also taken into account, and the appropriate additional amounts of minerals required for this volume were calculated (Table 2). In this manner, all the water consumed would contain the mineral being studied.

TABLE 2. Sources and predicted amounts of minerals to diluted into $3 \mathrm{~L}$ of water in the experiment, considering the maximum tolerable levels for the swine species. Uberlandia - MG, 2011.

\begin{tabular}{lccc}
\hline Mineral & Source & Mineral concentration in the source (\%) & $\mathbf{g} / \mathbf{3} \mathbf{L}$ of water \\
\hline $\mathrm{Mg}$ & $\mathrm{Mg}_{2} \mathrm{SO}_{4}$ & 9.10 & 9.89 \\
$\mathrm{Cu}$ & $\mathrm{Cu}_{2} \mathrm{SO}_{4}$ & 24.8 & 3.02 \\
$\mathrm{Se}$ & $\mathrm{Na}_{2} \mathrm{SeO}_{3}$ & 45.0 & 0.01 \\
$\mathrm{Zn}$ & $\mathrm{Zn}_{2} \mathrm{SO}_{4}$ & 20.3 & 14.77 \\
\hline
\end{tabular}

* Data provided by the manufacturer 
For both the treated and control groups, the volume of water was measured before and after the study, using the graded bucket. As such, the intake of the ions by the swine during the studied period could be calculated.

After $12 \mathrm{~h}$ of the administration of the respective hydric diets, the swine of both groups were slaughtered according to federal legislations (BRASIL, 2000). The animals were transported to the slaughter room through showers and were electrically stunned with two electrodes with an average voltage of $350 \mathrm{~V}$ and an average amperage of $0.85 \mathrm{~A}$. Next, they underwent bleeding, scalding, dehairing, evisceration, and inspection. Shortly after, the animals were stored in a cold room at a temperature of 0.5 to $2^{\circ} \mathrm{C}$.

For the analyses of meat color and WHC, meat samples were taken from the semimembranosus muscle (ham) $24 \mathrm{~h}$ after slaughter. The samples were obtained from the right-hand side of half-carcasses and were placed in plastic bags that had been previously numbered. For the WHC analysis, two samples of the muscle were taken from each animal.

The $\mathrm{pH}$ of the tenth rib of the left-hand side of half-carcasses was measured at $45 \mathrm{~min}$ and at $24 \mathrm{~h}$ with a portable digital $\mathrm{pH}$ meter (TESTO $205^{\mathrm{B}}$ ). The meter was calibrated with $\mathrm{pH} 4$ and 7 buffer solutions, which corresponded to the $\mathrm{pH}$ of the halfcarcasses measured at $24 \mathrm{~h}$ in the cold room $\left(0\right.$ to $\left.5^{\circ} \mathrm{C}\right)$.

The temperature of the longissimus dorsi muscle, between the second and third thoracic vertebrae, was measured at $1 \mathrm{~min}$ and at $24 \mathrm{~h}$ with a digital, mini stainless steel thermometer $\left(\mathrm{AKSO}^{\circledR}\right)$. The $\mathrm{HCW}$ (hot carcass weight) of all carcasses was measured using the same scale after the slaughter operations and before the carcasses were sent to the cold room.

WHC was measured by the compression method, according to GRAU \& HAMM (1953). Two meat cube samples of approximately $0.5 \mathrm{~g}$ were obtained from the inner central portion of the semimembranosus muscle from the left-hand side halfcarcasses. The cubes were weighed using a digital precision scale (OHAUS Scout $\left.\operatorname{Pro}^{\circledR}\right)$ and placed between two previously numbered filter papers (Whatman ${ }^{\circledR}$ No.1), which were placed between two acrylic plates. A 10-kg washer was then placed over the plates for $5 \mathrm{~min}$. Next, a ballpoint pen was used to contour the pressed meat sample on the back of the paper. The juice released around the sample stained the filter paper, thus forming two juxtaposed areas (GRAU \& HAMM, 1953).

These areas were scanned with a commercial scanner (Samsung® SCX 4200 series). The images were analyzed with Image $\mathrm{J} 1.37$, which is used for the development of digital imaging processing systems (ABRAMOFF et al., 2004).

The results were expressed as the ratio between the pressed area and the total area formed by the area of the meat plus the area of the juice released. This value ranged between 0 and 1, corresponding to the lowest and highest WHC, respectively. The average value of both samples was taken to be the final result.

Through these values of $\mathrm{WCH}$, the meats were classified as PSE $(\mathrm{WCH} \leq 0.4)$, Normal (WCH 0.4 to 0.6) and DFD (WCH $\geq 0.6$ ) (SAKATA et al.1989). Meat color classification was done visually following the Japanese Pork Color Scores (JPCS) standard, as used by ANTUNES et al. (2002). The standard uses a scale from one to six, with the ideal value for swine meat color being three. Colors one and two are lighter and can be used to evaluate PSE pork. Color four is still within the limit, despite 
being slightly darker. The samples with colors five and six are common in cases of DFD pork or in heavy and old animals.

The quantitative variables were subjected to the Normality (Lilliefors) and Homocedasticity (Cocran and Bartlett) tests, followed by analysis of variance (ANOVA). When significance was found, Tukey's test was performed to compare the averages at a $5 \%$ significance level. The color variable was assessed through MannWhitney's test. The variables PSE, normality, and DFD were compared through the chi-square method, taking WHC into account.

\section{RESULTS AND DISCUSSION}

The meat from the animals supplemented with $\mathrm{Mg}_{2} \mathrm{SO}_{4}$ showed significant $(\mathrm{p}<0.05)$ differences in $\mathrm{pH}$ (Table 3$)$, as compared to the control group. The group treated with $\mathrm{Mg}_{2} \mathrm{SO}_{4}$ had higher $\mathrm{pH}$ at $45 \mathrm{~min}$ (5.99) and at $24 \mathrm{~h}$ (5.81), as compared to the control group. In the control group, the $\mathrm{pH}$ at 45 min was 5.73, and the $\mathrm{pH}$ at 24 $\mathrm{h}$ was 5.53. ALONSO et al. (2012) reported also an increase in $\mathrm{pH}$ at $24 \mathrm{~h}$ in 40 gilts (Pietrain $\times$ (Landrace $\times$ Large White) that had received dietary Mg supplementation five days prior to slaughter. In the present study, the administration of Mg sources for $12 \mathrm{~h}$ prior to slaughter was enough to raise the observed $\mathrm{pH}$ values.

TABLE 3. Averages, standard deviation, and coefficient of variation (CV) for $\mathrm{pH}$ at $45 \mathrm{~min}$ and $\mathrm{pH}$ at $24 \mathrm{~h}$ for the meat from the swine in the control groups and those treated with minerals. Uberlandia - MG, 2011.

\begin{tabular}{|c|c|c|}
\hline \multicolumn{3}{|c|}{ pH 45' } \\
\hline & Control & $\mathrm{Mg}_{2} \mathrm{SO}_{4}$ \\
\hline Average & $5,73^{a} \pm 0,139$ & $5,99^{b} \pm 0,715$ \\
\hline \multirow[t]{2}{*}{$\mathrm{CV}$} & 2,42 & 11,93 \\
\hline & Control & $\mathrm{Na}_{2} \mathrm{SeO}_{3}$ \\
\hline Average & $6,00^{a} \pm 0,186$ & $6,20^{b} \pm 0,154$ \\
\hline \multirow[t]{2}{*}{ CV } & 3,10 & 2,48 \\
\hline & Control & $\mathrm{Cu}_{2} \mathrm{SO}_{4}$ \\
\hline Average & $6,13^{a} \pm 0,163$ & $5,99^{b} \pm 0,221$ \\
\hline \multirow{2}{*}{ CV } & 2,66 & 3,69 \\
\hline & Control & $\mathrm{Zn}_{2} \mathrm{SO}_{4}$ \\
\hline Average & $6,03^{a} \pm 0,146$ & $6,07^{a} \pm 0,244$ \\
\hline \multirow[t]{2}{*}{ CV } & 2,43 & 11,93 \\
\hline & \multicolumn{2}{|c|}{ pH 24 hours } \\
\hline & Control & $\mathrm{Mg}_{2} \mathrm{SO}_{4}$ \\
\hline Average & $5,53^{a} \pm 0,108$ & $5,81^{b} \pm 0,941$ \\
\hline \multirow[t]{2}{*}{ CV } & 3,05 & 16,19 \\
\hline & Control & $\mathrm{Na}_{2} \mathrm{SeO}_{3}$ \\
\hline Average & $5,67^{a} \pm 0,076$ & $5,78^{b} \pm 0,154$ \\
\hline \multirow[t]{2}{*}{$\mathrm{CV}$} & 1,35 & 1,61 \\
\hline & Control & $\mathrm{Cu}_{2} \mathrm{SO}_{4}$ \\
\hline Average & $5,76^{a} \pm 0,196$ & $5,72^{a} \pm 0,121$ \\
\hline \multirow[t]{2}{*}{ CV } & 3,40 & 2,12 \\
\hline & Control & $\mathrm{Zn}_{2} \mathrm{SO}_{4}$ \\
\hline Average & $5,73^{a} \pm 0,163$ & $5,79^{a} \pm 0,115$ \\
\hline CV & 2,85 & 11,19 \\
\hline
\end{tabular}

Averages are followed by different letters, indicating significant differences $(P<0.05)$ according to Tukey's test. 
More animals that were treated with magnesium were within the normal range for both characteristics, compared to the control animals. This can be attributed mainly to the fact that magnesium reduces the release of catecholamines from the nerve terminals, thus improving glycogenolysis and consequently, the $\mathrm{pH}$ values. The catecholamines increase heart rate, blood glucose and lactate level through the rapid breakdown of glycogen in the liver, which can also have some effects on meat quality (MOTA-ROJAS et al., 2012).

The average $\mathrm{pH}$ at $45 \mathrm{~min}$ and $\mathrm{pH}$ at $24 \mathrm{~h}$ of the animals supplemented with $\mathrm{Na}_{2} \mathrm{SeO}_{3}$ was higher ( $\mathrm{pH} 45$ min: 6.2; $\mathrm{pH} 24 \mathrm{~h}: 5.78$ ) than that of the control group ( $\mathrm{pH} 45$ min: 6; $\mathrm{pH} 24 \mathrm{~h}: 5.67)$. It is known that selenium is part of the enzyme glutathione peroxidase (GSH-Px) as seleno cysteine, and it is readily ionizable at physiological $\mathrm{pH}$. It protects the cell against free radicals in mammalian species that use the oxidative metabolism, and therefore it is crucial for cell survival by reducing hydrogen peroxide and lipid hydroperoxides (BOIAGO et al., 2014). The improvement in $\mathrm{pH}$ values found in this study may be associated with the intensification of this process in the muscle cells, thus diminishing $\mathrm{H}^{+}$-based compounds and reducing muscle acidification (Table 3).

At $45 \mathrm{~min}$, the animals from the group supplemented with $\mathrm{Cu}_{2} \mathrm{SO}_{3}$ had an average $\mathrm{pH}$ of 5.99, while those in the control group had an average $\mathrm{pH}$ of 6.13. The animals in the control group had a higher incidence of PSE meat and the $\mathrm{pH}$ at $45 \mathrm{~min}$ is an indicator to classify the meat with this anomaly (PETZET et al., 2013). According KIM et al. (2014) accelerated rates of muscle glycolysis early post-mortem result in low muscle $\mathrm{pH}$ when the muscle temperature is still high causing denaturation of muscle proteins and this denaturation contributes to the typical abnormal meat quality known as pale, soft and exudative (PSE). On the other hand, there was no difference in the average $\mathrm{pH}$ at $24 \mathrm{~h}$ in the groups studied, and the parameters that were found to be normal by TARSITANO et al. (2013) were maintained in our study.

In animals treated with $\mathrm{Zn}_{2} \mathrm{SO}_{4}$, no difference $(\mathrm{P}<0.05)$ was found for $\mathrm{pH}$ at 45 min or $\mathrm{pH}$ at $24 \mathrm{~h}$ (Table 3). Differently XU et al. (2017) when evaluating the effect of zinc supplementation on the pig carcass found values of 6.65 for $\mathrm{pH}$ at $45 \mathrm{~min}$ and of 5.45 for $\mathrm{pH} 24 \mathrm{~h}$.

No significant differences $(P<0.05)$ were found between the treated and control groups for the temperatures at $1 \mathrm{~min}$ and at $24 \mathrm{~h}$. As the energy reserves decline post-mortem, the muscles in the carcass enter rigor mortis and the muscle temperature drops, due to the cessation of blood supply and the application of chilling (KIM et al., 2014), in the present study, the administration of minerals did not influence heat loss in the animals right after bleeding or in the refrigerated carcass. There was also no difference in HCW among the groups studied (Table 4). The short administration time of $12 \mathrm{~h}$ may justify the absence of different results since a longer time of administration could be needed for changes in animal performance characteristics, such as weight gain, bacon thickness, and the percentage of lean meat. As such, these characteristics were not considered during the design of this research. 
TABLE 4. Averages and standard deviation (SD) for hot carcass weight (HCW) in the control and treated groups. Uberlandia - MG, 2011.

\begin{tabular}{lrrrr}
\hline & Control & \multicolumn{3}{c}{ Treatment } \\
\cline { 2 - 5 } & Average & SD & Average & \multicolumn{1}{l}{ SD } \\
\hline $\mathrm{Mg}$ & $73.73^{\mathrm{a}}$ & 11.01 & $74.86^{\mathrm{a}}$ & 14.51 \\
$\mathrm{Zn}$ & $77.51^{\mathrm{a}}$ & 11.78 & $73.02^{\mathrm{a}}$ & 11.60 \\
$\mathrm{Cu}$ & $72.55^{\mathrm{a}}$ & 9.52 & $71.57^{\mathrm{a}}$ & 8.97 \\
$\mathrm{Se}$ & $74.35^{\mathrm{a}}$ & 6.96 & $74.42^{\mathrm{a}}$ & 7.39 \\
\hline
\end{tabular}

Averages followed by different letters indicate significant differences $(P<0.05)$ according to Tukey's test.

No significant difference in WHC $(\mathrm{P}<0.05)$ was found between the control groups and the groups treated with $\mathrm{Mg}$, Se, or $\mathrm{Cu}$ (Table 5).

TABLE 5. Averages and standard deviation (SD) for WHC for meat from swine in the control and treated groups. Uberlandia - MG, 2011.

\begin{tabular}{lcrcc}
\hline & \multicolumn{2}{c}{ Control } & \multicolumn{3}{c}{ Treatment } \\
\cline { 2 - 5 } & Average & SD & Average & SD \\
\hline $\mathrm{Mg}$ & $0.366^{\mathrm{a}}$ & 0.528 & $0.499^{\mathrm{b}}$ & 0.787 \\
$\mathrm{Zn}$ & $0.443^{\mathrm{a}}$ & 0.140 & $0.404^{\mathrm{a}}$ & 0.068 \\
$\mathrm{Cu}$ & $0.447^{\mathrm{a}}$ & 0.059 & $0.386^{\mathrm{b}}$ & 0.102 \\
$\mathrm{Se}$ & $0.347^{\mathrm{a}}$ & 0.471 & $0.403^{\mathrm{b}}$ & 0.468 \\
\hline
\end{tabular}

Averages followed by different letters indicate significant differences $(P<0.05)$ according to Tukey's test.

As previously mentioned there is influence of $\mathrm{pH}$ on analyzes of meats of animals susceptible to stress, called meat-type PSE. These animals, when in stressful conditions, circulatory and respiratory systems feature disabled and after slaughter, the oxygen reserves are minimal and quickly deplete. In this context, the muscle refers to anaerobic mechanism for obtaining energy, causing decrease of muscle $\mathrm{pH}$, which, combined with high temperature causes denaturation of myofibrillar proteins affecting the WHC. In animal meats resistant to stress, called DFD meat type, the WHC is not changed, because the $\mathrm{pH}$ is close to the point physiological and proteins remain intact (PIRES et al., 2002).

A greater number of animals treated with $\mathrm{Mg}_{2} \mathrm{SO}_{4}$ were within the normal range for WHC (0.4 to 0.6), compared to the control animals.

When WHC was taken into consideration, $85 \%$ of the swine in the group treated with $\mathrm{Mg}_{2} \mathrm{SO}_{4}$ had meat that was considered normal, while $90 \%$ of the control group had PSE meat (Table 6). This is in accordance with the low average $\mathrm{pH}$ at 45 min of 5.8, which is a value related to PSE meat, that was found for the control group (KIM et al., 2014). The dietary Mg supplementation may counteract some of the detrimental effects of stress in swine and sheep (PYE et al., 2015). According CONSTANTINO et al. (2014), the stress activates the sympathetic nervous system by releasing catecholamines (epinephrine and norepinephrine), which are responsible for increasing respiratory rate, heart rate, body temperature and the expense of muscle glycogen. The increase of these catecholamines may raise the glycogenolysis rate, which has detrimental effects on meat quality. 
TABLE 6. Chi-square $\left(X^{2}\right)$ tests and $p$ values for PSE, normal, and DFD in the swine studied, according to the treatment groups. Uberlandia - MG, 2011.

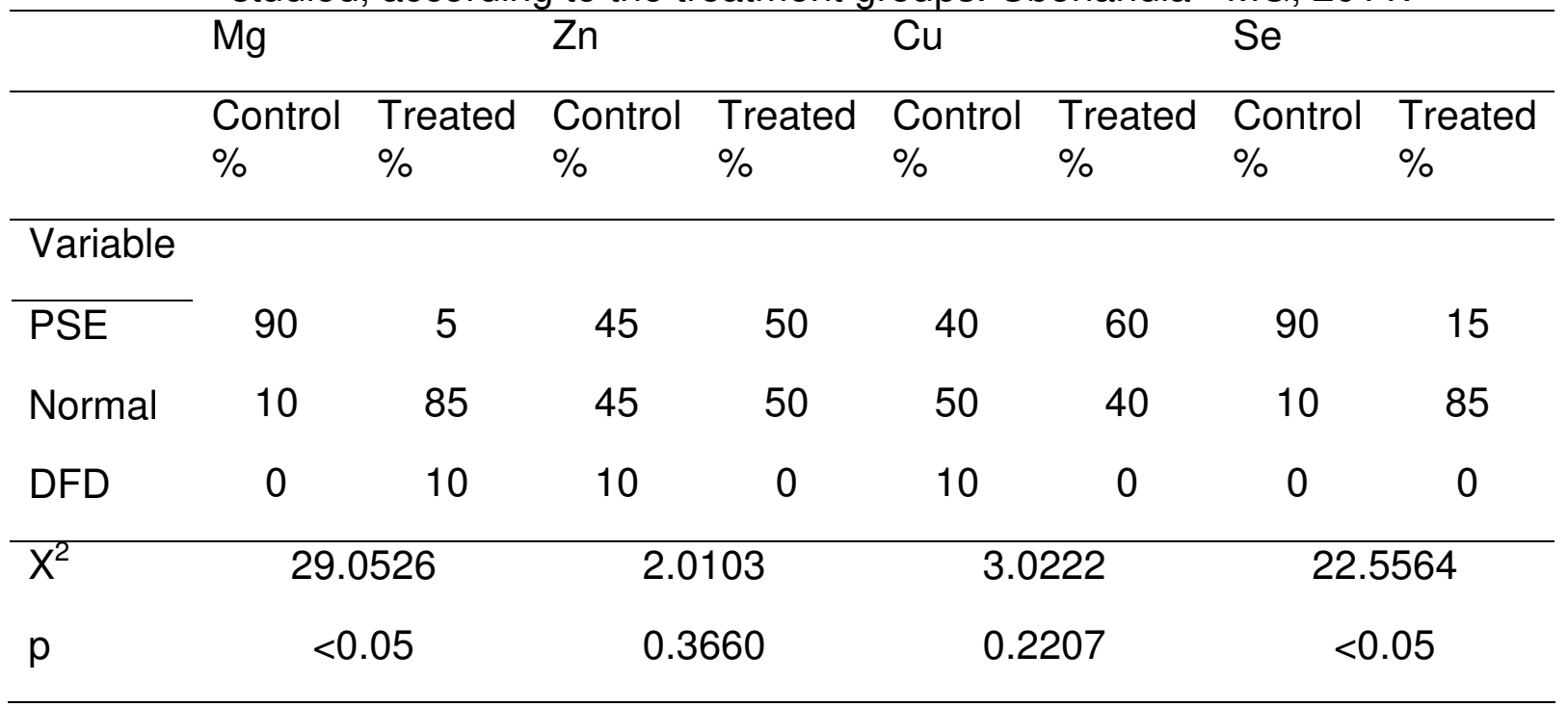

Only $15 \%$ of the swine supplemented with $\mathrm{Na}_{2} \mathrm{SeO}_{3}$ had PSE meat, while $90 \%$ of those in the control group had PSE meat (Table 6). It is known that antioxidant substances that are administered to animals are absorbed and incorporated into the cellular membrane. This causes a decrease in meat oxidation and, consequently, an increase in its shelf life. That may explain the lower incidence of PSE meat in the animals supplemented with $\mathrm{Na}_{2} \mathrm{SeO}_{3}$. This is in accordance with the studies carried out by LISIAK et al., (2014). These authors also reported that WHC was lower in the group of pigs supplemented with selenium. This is in accordance with the improved water holding capacity observed in the swine treated with $\mathrm{Na}_{2} \mathrm{SeO}_{3}$. Treatment with $\mathrm{Cu}_{2} \mathrm{SO}_{4}$ and $\mathrm{Zn}_{2} \mathrm{SO}_{4}$ did not affect the WHC.

The presence of PSE meats is the greatest contributor to the economic losses associated with lower-quality swine carcasses and may result from several factors that modulate muscle metabolism close to slaughter, including pre-slaughter nutritional management (MADDOCK et al., 2002). The incidence of PSE meat is also determined by genetics and may be induced by pre-slaughter management (MOURA et al., 2015).

The color of the meat from the animals supplemented with $\mathrm{Mg}_{2} \mathrm{SO}_{4}$ was statistically different $(P>0.05)$ from that of the other groups studied. Specifically, the animals from the control group had paler meat (2.55) than the treated group (3.60) (Table 7). A similar improvement in this characteristic was also found by MACHADO et al. (2008). This result may be related to the high amount of free water in the muscle tissue of the animals from the control group, caused by low $\mathrm{pH}$. This low amount of free water was previously shown to cause meat paleness as it increases enzymatic activity and, consequently, results in higher oxygen consumption and lower pigment proportions (PRADO, 2003). 
TABLE 7. Averages and standard deviation (SD) for meat color from swine in the control and treated groups. Uberlandia - MG, 2011.

\begin{tabular}{lcc}
\hline & \multicolumn{1}{c}{ Control } & Treatment \\
\cline { 2 - 3 } $\mathrm{Mg}$ & $2.55^{\mathrm{a}} \pm 0.510$ & Average \pm SD \\
$\mathrm{Zn}$ & $3.45^{\mathrm{a}} \pm 0.944$ & $3.60^{\mathrm{a}} \pm 0.598$ \\
$\mathrm{Cu}$ & $3.60^{\mathrm{a}} \pm 0.882$ & $3.40^{\mathrm{a}} \pm 0.502$ \\
$\mathrm{Se}$ & $2.95^{\mathrm{a}} \pm 0.510$ & $3.40^{\mathrm{a}} \pm 0.680$ \\
\hline $\mathrm{Av}$ & & $3.00^{\mathrm{a}} \pm 0.458$ \\
\hline
\end{tabular}

Averages followed by different letters indicate significant differences $(P<0.05)$ according to Mann-Witney's test.

As DUGAN et al. (2004) magnesium decreases drip loss and consequently improves the color of the meat. APPLE et al. (2002) showed that magnesium inhibits lipid oxidation in meat during storage, a characteristic that positively influences the color of the meat.

\section{CONCLUSION}

Through the characteristics analyzed magnesium and selenium supplementation in drinking water for pigs 12 hours before slaughter can be used as improved meat quality. This study showed that supplementation of mineral water is advantageous because it is done only 12 hours before slaughter and a shorter period than in a diet for pre slaughter pigs.

\section{REFERENCES}

ABPA. Associação Brasileira de Proteína Animal. Relatório Anual 2016. Disponível em:<http://abpabr.com.br/storage/files/versao_final_para_envio_digital_1925a_final_a bpa_relatorio_anual_2016_portugues_web1.pdf. 2016>. Acesso em: 23 de janeiro de $201 \overline{7}$.

ABRAMOFF, M. D., MAGALHÃES, P. J., RAM, S. J. Image processing with ImageJ. Biophotonics International, Pittsfield, v. 11, n.7, p. 36-42, 2004.

ALONSO, V.; PROVINCIAL, L.; GIL, M.; GUILLÉN, E.; RONCALÉS, P.; BELTRÁN, J. A. The impact of short-term feeding of magnesium supplements on the quality of pork packaged in modified atmosphere. Meat Science, v. 90, p. 52-59, 2012. Disponível em: http://dx.doi.org/10.1016/j.meatsci.2011.05.028>. doi: 10.1016/j.meatsci.2011.05.028

ANTUNES, R. C., PITA, F. V. C., FRANCO, M. M., GOULART FILHO, L. R. Influência da composição racial da linha materna e do genótipo HAL sobre a qualidade da carne em suínos abatidos entre 90 e $110 \mathrm{~kg}$ de peso vivo. Ars Veterinária, Jaboticabal, v.18, n.1, p. 33-42, 2002.

APPLE, J. K.; MAXWELL, C. V.; STIVARIUS, M. R.; RAKES, L. K.; JOHNSON, ZELPHA B. Effects of dietary magnesium and halothane genotype on performance and carcass traits of growingfinishing swine. Livestock Production Science, 
Amsterdan, v. 76, n. 1, p. 103-113, 2002. Disponível em:< http://dx.doi.org/10.1016/S0301-6226(02)00004-0>. doi: 10.1016/S03016226(02)00004-0

BOIAGO, M. M.; BORBAI, H.; LEONEL, F. R.; GIAMPIETRO-GANECO, A.; FERRARI, F. B.; STEFANI, L. M.; SOUZA, P. A. Sources and levels of selenium on breast meat quality of broilers. Ciência Rural, v.44, n.9, p. 1692-1698, 2014. Disponível em:< http://dx.doi.org/10.1590/0103-8478cr20131256>. doi: 10.1590/0103-8478cr20131256

BRASIL. Ministério da Agricultura, Pecuária e Abastecimento. Secretaria de Defesa Agropecuária-DAS. Departamento de Inspeção de Produtos de Origem AnimalDIPOA. Divisão de Normas Técnicas- DNT. Regulamento Técnico de Métodos de Insensibilização para o Abate Humanitário de Animais de Açougue. Diário Oficial da União, Brasília, DF, 2000.

CALVO, L.; TOLDRÁ, F.; ARISTOY, M.C.; LÓPEZ-BOTE, C.J.; REY, A.I. Effect of dietary organic selenium on muscle proteolytic activity and water-holding capacity in pork. Meat Science, v. 121, p. 1-11, $2016 . \quad$ Disponível em: http://dx.doi.org/10.1016/j.meatsci.2016.05.006>. doi: 10.1016/j.meatsci.2016.05.006

CONSTANTINO, C.; RIBEIRO, E. L. A.; BRIDI, A. M.; TARSITANO, M. A.; CASTRO, F. A. B.; JÚNIOR, F. F.; YURIKAMIZUBUTI, I.; PEREIRA, E. S. Performance, carcass and meat quality of ewes supplemented with magnesium oxide. Revista Brasileira de Zootecnia, v.43, n.1, p.27-35, 2014. Disponível em:< http://dx.doi.org/10.1590/S1516-35982014000100005>. Doi: 10.1590/S151635982014000100005.

DJINOVIC-STOJANOVIC, J. M.; NIKOLIC, D. M.; VRANIC, D. V.; BABIC, J. A.; MILIJASEVIC, M. P.; PEZO, L. L.; JANKOVIC, S. D. Zinc and magnesium in different types of meat and meat products from the Serbian market. Journal of Food Composition and Analysis, v. 59, p. 50-54, $2017 . \quad$ Disponível em: <http://dx.doi.org/10.1016/j.jfca.2017.02.009>. doi: 10.1016/j.jfca.2017.02.009

DUGAN, M. E. R.; AALHUS, J. L.; UTTARO, B. Nutritional manipulation of pork quality: Current Opportunities. Advances in Pork Production, Lacombe, v. 15, $\mathrm{p}$ 237-243, 2004.

GRAU, R.; HAMM, R. Eine einfache methode zur bestimmung der wasserbindung in muskel. Naturwissenschaften, v. 40, p. 29-30, 1953. Disponível em:< http://link.springer.com/10.1007/BF00595734>. doi: 10.1007/BF00595734

KIM, Y. H. B.; WARNER, R. D.; ROSENVOLD, K. Influence of high pre-rigor temperature and fast $\mathrm{pH}$ fall on muscle proteins and meat quality: a review. Animal Production Science, v.54, p. 375-395, 2014. Disponível em: < http://dx.doi.org/10.1071/AN13329>. doi: 10.1071/AN13329 
KIM, T. W.; KIM, C. W.; YANG, M. R.; NO, G. R.; KIM, S. W.; KIM, S. Pork Quality Traits According to Postmortem $\mathrm{pH}$ and Temperature in Berkshire. Korean Journal Food Science Animal, v. 36 (1), p. 29-36, 2016. Disponível em: <http://dx.doi.org/10.5851/kosfa.2016.36.1.29>. doi: 10.5851/kosfa.2016.36.1.29

LISIAK, D.; JANISZEWSKI, P.; BLICHARSKI, T.; BORZUTA, K.; GRZEŚKOWIAK, E.; LISIAK, B.; POWAŁOWSKI, K.; SAMARDAKIEWICZ, Ł.; BATORSKA, M.; SKRZYMOWSKA, K.; HAMMERMEISTER, A. Effect of selenium supplementation in pig feed on slaughter value and physicochemical and sensory characteristics of meat. Annals of Animal Science, v. 14, n. 1, p. 213-222, 2014. Disponível em: < https://doi.org/10.2478/aoas-2013-0063>. doi: 10.2478/aoas-2013-0063

MACHADO, O. D.; FONTES, D. O.; FERREIRA, J. M.; CORRÊIA, G. S. S.; NELSON, D. L.; GLÓRIA, M. B. A. Desempenho e qualidade da carne de suínos suplementados com magnésio e creatina no período pré-abate. Brazilian Journal of Food Technology, Campinas, v. 11, n. 3, p. 211-220, 2008. Disponível em:< http://www.ital.sp.gov.br/bj/artigos/bjft/2008/v11n3bjft6907.pdf>. Acesso em: 23 de janeiro de 2017.

MADDOCK, R. J.; BIDNER, B. S.; CARR, S. N.; MCKEITH, F. K.; BERG, E. P.; SAVELL, J. K. Creatine monohydrate supllementation and the quality of fresh pork in normal and halothane carrier pigs. Journal of Animal Science, Champaign, v. 80, n. 4, p 2002. 997-1004, Disponível em: < https://www.animalsciencepublications.org/publications/jas/pdfs/80/4/997>. doi: doi: $10.2527 / 2002.804997 x$

MATEESCU, R. G. ; GARMYN, A. J.; TAIT JR., R. G. ; DUAN, Q. ; LIU, Q. ; MAYES, M. S. ; GARRICK, D. J.; VAN EENENNAAM, A. L.; VANOVERBEKE, D. L. ; HILTON, G. G.; BEITZ, D. C. ; REECY, J. M. Genetic parameters for concentrations of minerals in longissimus muscle and their associations with palatability traits in Angus cattle. Journal of Animal Science, v. 91, p. 1067-1075, 2013. Disponível em: https://www.animalsciencepublications.org/publications/jas/pdfs/91/3/1067>.doi:10.25 27/jas.2012-5744

MOTA-ROJAS, D.; BECERRIL-HERRERA, M.; ROLDAN-SANTIAGO, P.; ALONSOSPILSBURY, M.; FLORESPEINADO, S.; RAMÍREZ-NECOECHEA, R.; RAMÍREZTELLES, J.A.; MORA-MEDINA, P.; PÈREZ, M.; MOLINA, E.; SONÍ, E.; TRUJILLOORTEGA, M.E. Effects of long distance transportation and Co2 stunning on critical blood values in pigs. Meat Science, v. 90, p. 893-898, $2012 . \quad$ Disponível em:< http://dx.doi.org/10.1016/j.meatsci.2011.11.027>. doi: 10.1016/j.meatsci.2011.11.027

MOURA, J. W. F.; MEDEIROS, F. M.; ALVES, M. G. M.; BATISTA, A. S. M. Fatores Influenciadores na Qualidade da Carne Suína. Revista Científica de Produção Animal, v.17, n.1, p.18-29, 2015. Disponível em:< http://dx.doi.org/10.15528/21764158/rcpa.v17n1p18-29>. doi: 10.15528/2176-4158/rcpa.v17n1p18-29

NRC: National Research Council. Mineral tolerance of animals. 2th ed.. 
Washington: National Academic Press, 2005.

PETZET, A.; SCHEIER, R.; OCTOVIANI, A.; BAUER, A.; HAMMON, A.; DIEPOLDER, $\mathrm{H}_{\text {.; }}$ SCHMIDT, $\mathrm{H}_{\text {.; }}$ SCHWÄGELE, $\mathrm{F}$. Entwicklung von Analysemethoden zur Etablierung eineronline-fähigen Beurteilung der Fleischqualität. Fleischwirtschaft, v.93, p.84-87, 2013.

PIRES, I. C. C.; ROSADO, G. P.; AZEVEDO, R. M. C.; NEVES, M. B.; MIRANDA, L. S. Composição centesimal, perdas de peso e maciez de lombo (Iongissimus dorsi) suíno submetido a diferentes tratamentos de congelamento e descongelamento. Revista de Nutrição, Campinas, v. 15, n.2, p. 45-52, 2002. Disponível em: <http://dx.doi.org/10.1590/S1415-52732002000200005>. doi: 10.1590/S141552732002000200005

PRADO, C. S. Propriedades da carne fresca. Curso de especialização em inspeção e tecnologia de produtos de origem Animal. Goiânia, Brazil: Universidade Federal de Goiás, 2003.

PYE, J. L.; DOYLE, R. E.; FRIEND, M. A.; BHANUGOPAN, M. S. Effect of dietary magnesium supplementation in alleviating stress associated with road transportation in weaned lambs. Animal Production Science, v. 55, p. 219-224, 2015. Disponível em: <http://dx.doi.org/10.1071/AN14288>. doi: 10.1071/AN14288

SAKATA, R.; DEGUCHI, T.; NAGATA, Y. Assessment of rapid method for determining water holding capacity in meat. In: INTERNATIONAL CONGRESS OF MEAT SCIENCE AND TECHNOLOGY, Copenhagen. Anais...Copenhagen 1989, p. 181-181.

TARSITANO, M. A.; BRIDI, A. M.; SILVA, C. A.; CONSTANTINO, C.; ANDREO, N.; DALTO, D. B. Magnesium supplementation in swine finishing stage: performance, carcass characteristics and meat quality. Semina: Ciências Agrárias, v. 34, n. 6, p. 3105-3118, 2013. Disponível em: <http://dx.doi.org/10.5433/16790359.2013v34n6p3105>. doi: 10.5433/1679-0359.2013v34n6p3105

TOMOVIC, V. M.; ZLENDER, B. A.; JOKANOVIC, M. R.; TOMOVIC, M. S.; SOJIC, B. V.; SKALJAC, S. B.; TASIC, T. A.; IKONIC, P. M.; SOSO, M. M.; HROMIS, N. M. Technological quality and composition of the $M$. Semimembranosus and $M$. Longissimus dorsi from Large White and Landrace Pigs. Agricultural and Food Science, v.23, p. 9-18, 2014. Disponível em: <http://journal.fi/afs/article/view/8577>.

XU, X.; LIU, L.; LONG, S. F.; PIAO, X. S.; WARD, T. L.; JI, F. Effects of Chromium Methionine Supplementation with Different Sources of Zinc on Growth Performance, Carcass Traits, Meat Quality, Serum Metabolites, Endocrine Parameters, and the Antioxidant Status in Growing-Finishing Pigs. Biological Trace Element Research, p.1-9, 2017. 